Journal of Clinical Investigation

Vol. 41, No. 1, 1962

\title{
PHENYLALANINE METABOLISM IN THE PHENYLPYRUVIC CONDITION. II. AN ATTEMPT TO CALCULATE THE DAILY INCORPORATION OF PHENYLALANINE INTO PROTEINS *
}

\author{
BY HANNS-DIETER GRÜMER, HANS KOBLET AND CAROL WOODARD
}

(From the Arthur G. Rotch Research Laboratories, The Boston Dispensary, Boston, Mass., and the Biochemical Laboratory, Pineland Hospital and Training Center, Pozenal, Me.)

(Submitted for publication March 25, 1960 ; accepted September 21, 1961)

Some attempts have been made to estimate the rate of total protein synthesis in man. San Pietro and Rittenberg (1), in an improvement of a previous model of Sprinson and Rittenberg (2), used a three-compartment scheme, containing a protein pool, a metabolic nitrogen pool, and a urea pool. They compared the mathematical formula derived on the basis of these assumptions with the empirical formula, given by the $\mathrm{N}^{15}$-excretion curve in the urine. Their basic assumptions are a nonrate-limiting transamination, and that all amino acids are used for protein synthesis, oxidation, and nitrogen excretion. A similar model was used by $\mathrm{Wu}$, Sendroy and Bishop (3-5). Maurer (6) estimated the daily protein formation from the rate of disappearance of intravenously injected $\mathrm{S}^{35}$ methionine. However, it seemed worthwhile to carry out calculations of the daily amount of protein formation in phenylketonuric patients, where metabolism of one amino acid is slowed down and data can be obtained with greater accuracy from the graphic plot.

In the preceding paper ( 7$)$ we described the determination of the free phenylalanine pool and its maximal turnover rate in patients suffering from phenylpyruvic oligophrenia. This turnover rate applies only to this group of patients because of their negligible ability to convert phenylalanine to tyrosine; but such a metabolic defect makes them useful models in whom to study the rate of protein synthesis in man.

Experiments by Udenfriend and Bessman (8) demonstrated that, on a molar basis, only about 2 per cent of the phenylalanine is converted to tyrosine in this disease; this means that the main pathway in the metabolism of phenylalanine is es-

\footnotetext{
* This work was supported by Grants 2729 and 3g61 from the National Institute of Mental Health.
}

sentially blocked. Thus, the assumption that phenylalanine can only be stored, excreted, or incorporated into proteins is reasonable, and further evidence for this hypothesis will be given. With this assumption, together with the calculated pool size and the turnover time, it should be possible to estimate daily incorporation of phenylalanine into proteins.

\section{MATERIAL AND METHODS}

Patients, and blood samples withdrawn on the second day, were the same as those used in the preceding paper, except that we carried out one more experiment in one patient (J.I.2).

For determination of the total counts in plasma, $0.5-\mathrm{ml}$ plasma aliquots were plated in duplicate on plastic planchets and dried overnight at room temperature. The radioactivity of the plasma proteins was determined by subtracting the counts per minute in $1.0 \mathrm{ml}$ deproteinized plasma from those of $1.0 \mathrm{ml}$ total plasma at any given time. That these differences were really due to incorporation of labeled phenylalanine was occasionally checked in control experiments with isolated and washed plasma proteins. The trichloroacetic acid (TCA)-precipitated proteins were dissolved in $10 \mathrm{ml}$ dilute $\mathrm{NaOH}$ containing 1 per cent unlabeled phenylalanine, and reprecipitated by the addition of $0.6 \mathrm{M} \mathrm{TCA}$. This procedure was repeated four times; unlabeled phenylalanine was dissolved in $5 \mathrm{ml}$ of $6 \mathrm{~N} \mathrm{HCl}$, and hydrolyzed in an ampule for 16 hours at $110^{\circ} \mathrm{C}$. The insoluble products were removed by centrifugation from the supernatant and were washed three times in a small amount of water. The collected supernatants were evaporated to dryness. The dry material was taken off in 2 to $2.5 \mathrm{ml}$ of water, and then quantitatively transferred to a centrifuge tube and separated from insoluble material. The supernatant was again quantitatively transferred to a graduated centrifuge tube and made up to a final volume of 4 to $6 \mathrm{ml}$. One-quarter of it was plated, and the rest was transferred to a Dowex-50 $\mathrm{Na}^{+}$column $(150 \mathrm{~cm})$ and chromatographed with $0.2 \mathrm{M}$ sodium citrate, $\mathrm{pH}$ 4.25. The tyrosine and phenyalanine fractions, identities of which were confirmed by paper chromatography, were pooled sepa- 
rately, and the amino acid content was determined by quantitative ninhydrin reaction (9).

Urine was obtained by voluntary urination and $1.0-\mathrm{ml}$ aliquots were plated on plastic planchets for counting.

It was possible to train one patient (K.H., IQ $=30$ SB-L) to breathe for a few minutes, at hourly intervals, into a bottle containing saturated barium hydroxide. The resulting $\mathrm{BaCO}_{3}$ was centrifuged, washed with distilled water and plated on aluminum planchets. All radioactivity data were expressed as counts per minute per milliliter, unless otherwise stated, and were corrected for background and self-absorption.

For determination of the turnover rate of plasma proteins, Patient J.I. received $15 \mu \mathrm{c}$ L-phenylalanine-U-C ${ }^{\mathbf{1 4}}$ orally when her plasma phenylalanine was adjusted to $3.4 \mathrm{mg}$ per $100 \mathrm{ml}$. Two hours after the injection of the radioisotope the patient was placed on a normal diet.

\section{RESULTS AND DISCUSSION}

During one turnover time of the phenylalanine pool, 2 to 5 per cent of the total amount administered was excreted into the urine, less than 1 per cent was expired as $\mathrm{CO}_{2}$, and-calculated from experiments by Udenfriend and Bessman (8)about 2 per cent was converted to tyrosine. The fraction of phenylalanine converted to hippuric acid was estimated to be, in $\mathrm{K} . \mathrm{H}_{2}$, between 0.28 and 3.6 per cent, and in R.S. between 0.39 and 5.7 per cent (10). In Patient R.S. the urinary hippuric acid was hydrolyzed and the radioactivity of the resulting benzoic acid showed the same specific activity as the hippuric acid. This indicates that no appreciable amount of labeled phenylalanine was converted to glycine and other nonaromatic compounds. It is therefore reasonable to assume that the excretion and the conversion of phenylalanine to other compounds amount to not more than roughly 10 per cent. In other words, more than about 90 per cent of the free phenylalanine pool is retained in the body within one turnover time.

The average phenylalanine content of proteins, in general, has been determined to be 4 to $6 \mathrm{~g}$ per $100 \mathrm{~g}$ protein. For plasma proteins we determined, in agreement with other authors (11), an average phenylalanine content of $6 \mathrm{~g}$ per $100 \mathrm{~g}$ protein.

In the preceding paper we discussed two models. One was based on the assumption that the first straight line reflects not turnover only but, also, unfinished equilibration processes involving labeled phenylalanine. Two compartments might then exist in regard to metabolic activities of phenylalanine; namely, a metabolically more active and a metabolically less active body compartment. Therefore, all calculations from the first straight line are only upper limits for turnover going on in the metabolically more active body compartment. The other model, which we preferred, assumes that equilibration of the labeled phenylalanine within the body is complete, or essentially complete, when the first straight line starts, and that turnover calculated from this line reflects true turnover of the total free phenylalanine pool in the body. If this be so, the extrapolation of the first straight line to zero time $\left(t_{0}\right)$ permits the calculation of the total free phenylalanine pool. If a fraction of 90 per cent of the free phenylalanine pool in one turnover time is incorporated into body proteins, the daily incorporation of phenylalanine can be calculated $:^{1}$

$$
\begin{aligned}
\frac{t_{r} \times 0.9 \times 1,440}{165}(\mathrm{mEq} \text { phenylalanine } \\
\text { incorporated per day })
\end{aligned}
$$

where $t_{r}=$ absolute turnover rate of free phenylalanine (mg per $\min ) ; 1,440=$ minutes per day ; $165=$ milligram equivalent weight of phenylalanine.

The daily protein formation can be estimated, if uniform distribution of the labeled phenylalanine within the newly synthesized protein molecules is assumed. In Equation 2 the average phenylalanine content of body proteins is estimated to be 5

1 Actually, less than 90 per cent is incorporated into body proteins within one turnover time, if it be assumed that exactly 10 per cent of the administered labeled phenylalanine is converted to other compounds and excreted. That this is less than 90 per cent is owing to the fact that, within one turnover time, the labeled phenylalanine has dropped to 37 per cent of its original value (or 63 per cent of the phenylalanine molecules present at zero time has left the free phenylalanine pool within one turnover time). Consequently, the true correction factor should be 0.84 and not 0.90 . Thus, the incorporation values in Equations 1 and 2 would be 6 per cent too high. If a total of only 7 per cent of the administered label were converted to other compounds or excreted, the correction factor would be 0.89 and the incorporation values only 1 per cent too high. Since it was calculated that the upper limit for conversion and excretion of free phenylalanine was 10 per cent, the factor of 0.9 was used, and no further correction was attempted. 
per cent :

$$
\frac{t_{r} \times 0.9 \times 1,440}{0.05 \times 1,000}(\mathrm{~g} \text { protein per day })
$$

Uptake of free phenylalanine by a protein precursor pool and by protein synthesis is fast. Significant labeling of plasma proteins occurred in $\mathrm{J.I}_{._{1}}$, J.I. , and K.H. within 30 minutes, and in N.C. within 45 minutes after the injection of the radioisotope. This early labeling of plasma proteins is in agreement with studies by other authors. They found lag periods of about 20 minutes for unfractionated serum proteins (12) and about 30 minutes for isolated $\gamma$-globulins (13) after the injection of radioactive amino acids. The fact that significant incorporation is found after so short an interval is in agreement with the assumption that the first straight line reflects turnover rather than continued equilibration of free phenylalanine.

In Figure 1 the relationship of the curve of total plasma counts, the counts in the supernatant, and the calculated counts in plasma proteins is shown. The results, as calculated from Equations 1 and 2, are summarized in Table I and compared with the data of other authors in Table II. It may be seen that our values agree best with those given by San Pietro and Rittenberg (1). These workers stated that their data are lower limits of daily protein synthesis. Our values are either true approxima-

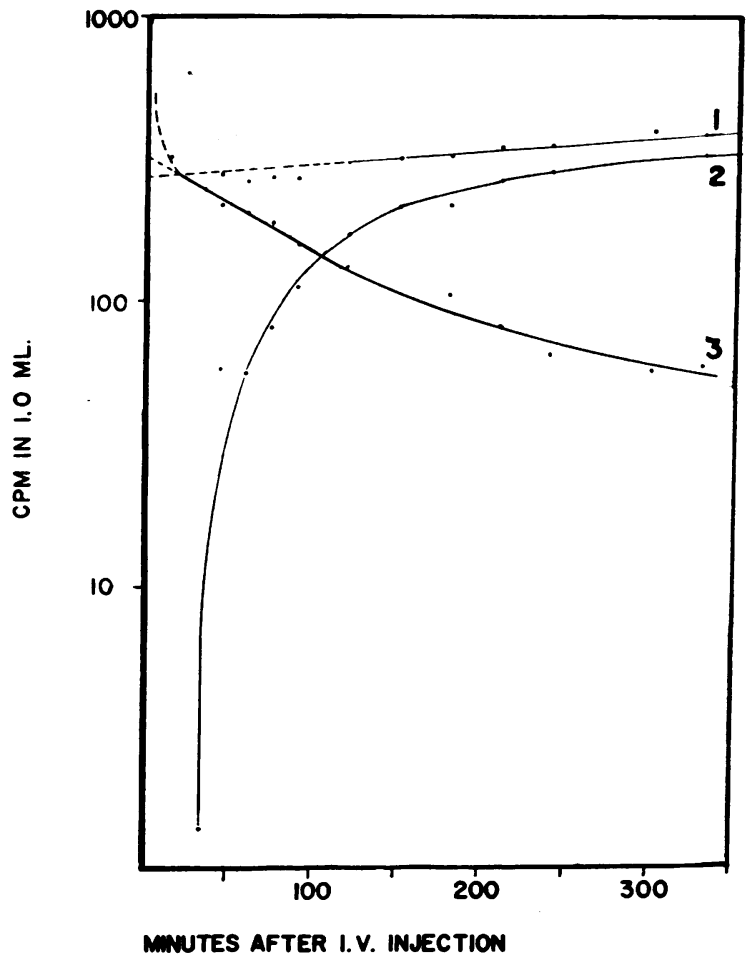

Fig. 1. EXAMple of THE TIME COURSE OF L-PHENYLALANINE-C ${ }^{14}$ IN DifFERENT PLASMa FRACTIONS IN PATIENT N.C. CPM in $1.0 \mathrm{ml}$ plasma (1) and in $1.0 \mathrm{ml} \mathrm{de-}$ proteinized plasma (3). Curve 2 represents the incorporation of $\mathrm{L}$-phenylalanine- $\mathrm{C}^{16}$ into plasma proteins in $1.0 \mathrm{ml}$ plasma, as obtained by subtracting the values of curve 3 from those of curve 1 .

TABLE I

Summary of phenylalanine incorporation into proteins, daily protein synthesis, and excretion of $C^{14}$

\begin{tabular}{|c|c|c|c|c|c|}
\hline & \multicolumn{5}{|c|}{ Patient } \\
\hline & J.I.1 & J.I.2 & N.C. & K.H.1 & K.H.2 \\
\hline \multicolumn{6}{|c|}{ Excretion of $\mathrm{C}^{14}$ for 6 hours (\% dose) } \\
\hline $\begin{array}{l}\text { Respiratory } \mathrm{CO}_{2} \\
\text { Urine }\end{array}$ & 2.5 & 1.5 & & 2.4 & $\begin{array}{l}0.3 \\
4.7\end{array}$ \\
\hline \multicolumn{6}{|c|}{ Absolute turnover rate $\left(m g \times m i n^{-1}\right)$} \\
\hline $\begin{array}{l}\text { Absolute weight } \\
70 \mathrm{~kg} \text { body wt }\end{array}$ & $\begin{array}{l}19.2 \\
21.2\end{array}$ & & $\begin{array}{l}12.7 \\
17.2\end{array}$ & $\begin{array}{l}11.7 \\
13.7\end{array}$ & $\begin{array}{l}10.4 \\
13.6\end{array}$ \\
\hline \multicolumn{6}{|c|}{$\begin{array}{c}\text { Phenylalanine incorporation into } \\
\text { body proteins }(m E q / \text { day })\end{array}$} \\
\hline $\begin{array}{l}\text { Absolute body wt } \\
70 \mathrm{~kg} \text { body wt }\end{array}$ & $\begin{array}{l}150 \\
166\end{array}$ & & $\begin{array}{l}100 \\
135\end{array}$ & $\begin{array}{r}92 \\
107\end{array}$ & $\begin{array}{r}82 \\
107\end{array}$ \\
\hline \multicolumn{6}{|c|}{ Expressed as protein $(g)$} \\
\hline $70 \mathrm{~kg}$ body $\mathrm{wt}^{*}$ & 545 & & 445 & 353 & 353 \\
\hline
\end{tabular}

* Phenylalanine content of proteins estimated to be $\mathbf{5}$ per cent. 
tions or upper limits, depending on which of our two basic assumptions is correct in regard to the end of equilibration processes of the labeled phenylalanine when the first straight line starts.

In Patient R.S., described in the preceding paper, it was deemed not advisable to calculate the incorporation rate, since his plasma phenylalanine level was so high that phenylpyruvic acid was excreted.

It was also of interest to obtain some estimate of the rate of plasma protein formation. Since the ascending curve of the incorporation of the radioactive amino acid into plasma proteins does not permit a sound calculation of the turnover rate of plasma proteins, we had to obtain this rate from the descending part. Therefore, we extended our time of observation to 5 weeks. A subject for this study was again Patient J.I., about 16 months after the first experiment. In contrast to the other patients, J.I..$_{2}$ obtained the labeled L-phenylalanine by mouth. This was done to achieve a maximal incorporation of labeled phenylalanine into plasma proteins, since the liver by its anatomical location is likely to pick up more amino acids if they are absorbed by the intestine. The advantage of repeating this study in a previously used patient is that protein synthesis in one individual may be constant, permitting a more accurate approximation of the fraction of plasma proteins formed, as compared with the total body protein synthesis, than would have been possible by comparison of two different individuals. When Patient ${\mathrm{J} . \mathrm{I}_{2}}_{2}$ obtained the radioactive phenylalanine, her plasma phenylalanine concentration was

TABLE II

Daily rate of protein formation in man as obtained by various authors after the application of a labeled amino acid*

\begin{tabular}{|c|c|c|c|}
\hline Authors & Expts. & $\begin{array}{l}\text { Average protein } \\
\text { synthesized }\end{array}$ & $F$ \\
\hline $\begin{array}{l}\text { San Pietro and } \\
\text { Rittenberg (1) }\end{array}$ & $\begin{array}{c}\text { no. } \\
4\end{array}$ & $\begin{array}{c}\mathrm{g} / 70 \mathrm{~kg} / \mathrm{day} \\
>330+194 \\
-149\end{array}$ & $16 \%$ nitrogen \\
\hline Wu et al. (5) & 6 & $\begin{array}{r}148+31 \\
-22\end{array}$ & $16 \%$ nitrogen \\
\hline Maurer (6) & 4 & $\sim 800$ & Not specified \\
\hline This study & 4 & $\leqq 424+121$ & $5 \%$ phenyl. \\
\hline
\end{tabular}

* The calculation of grams protein formed was made under the assumption that the average nitrogen or phenylalanine content of proteins is that given in column F.

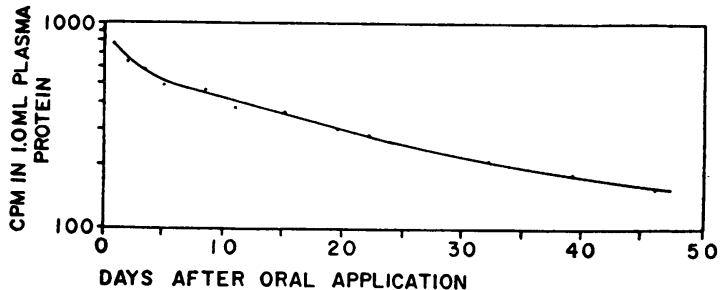

Fig. 2. Disappearance of $\mathrm{C}^{14}$-Labeled phenylalanine FROM PLASMA PROTEINS.

$3.4 \mathrm{mg}$ per $100 \mathrm{ml}$. Since it is known that recycling of labeled amino acids released from proteins results in apparent lower turnover rates of plasma proteins, we placed Patient J.I., 2 hours ${ }^{2}$ after the oral application of phenylalanine- $\mathrm{C}^{14}$, on a normal diet in which the first meal was rich in proteins. In this way we increased the free phenylalanine plasma level to $42.5 \mathrm{mg}$ per $100 \mathrm{ml} 4$ days later. Consequently, the free phenylalanine pool was diluted about 15 -fold and phenylalanine and its derivatives, phenylpyruvic acid and phenylacetic acid, were excreted in appreciable amounts, thus minimizing recycling of labeled phenylalanine from plasma proteins.

Figure 2 demonstrates the disappearance of phenylalanine- $\mathrm{C}^{14}$ from plasma proteins. A straight line existed between Days 5 and 25. Following the conventional methods the turnover time and relative turnover rate of plasma proteins were calculated from the slope of this line. The turnover time was 28.4 days and $1 / t_{t}$ was $0.035 \times$ days $^{-1}$. This value is in reasonable agreement with the turnover rate of infused cysteine- $S^{35}$-labeled plasma proteins by Volwiler and co-workers (14), who obtained half-lives corresponding to turnover times of about 19 and 35 days. The intravascular plasma protein concentration was determined to be $7.4 \mathrm{~g}$ per $100 \mathrm{ml}$ and the intravascular plasma space (Evans blue space) $2.16 \times 10^{3} \mathrm{ml}$. Assumed that the total plasma protein in the extravascular space is 1.4 times that of the intravascular space, the daily plasma protein synthesis can

2 The time of 2 hours was not arbitrarily chosen. The known plasma phenylalanine concentration and the known antipyrine space permitted a rough estimate of the free phenylalanine pool. From Figure 2 in the preceding paper (7) a corresponding turnover time of about 1 hour for a free phenylalanine pool of a little more than $1 \mathrm{~g}$ per 70 $\mathrm{kg}$ was predicted. Since J.I. obtained the labeled phenylalanine by mouth, an additional hour was allowed for absorption of the label from the intestine. 


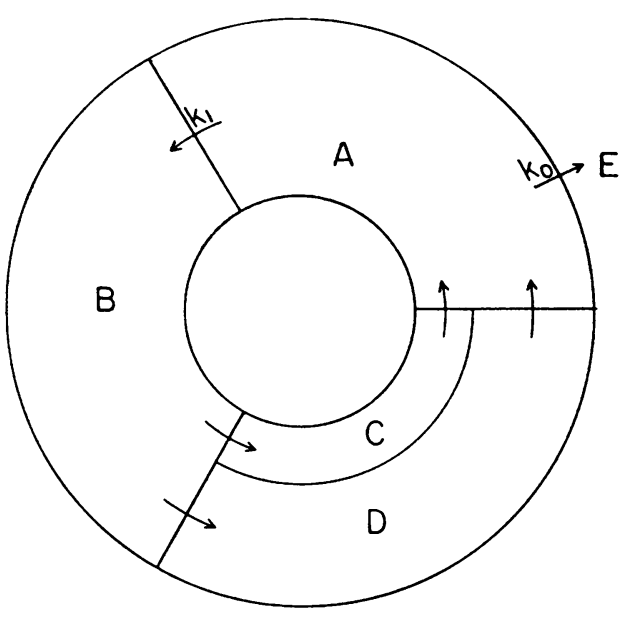

Fig. 3. Simplified Model Representing the fate of Phenylalanine. $\mathrm{A}=$ free phenylalanine pool. $\mathrm{B}=$ phenylalanine-containing protein precursor pool. $\mathrm{C}=$ phenylalanine-containing plasma protein pool. $\mathrm{D}=$ phenylalanine-containing total body protein pool minus compartment $C . E=$ urinary excretion of free phenylalanine and conversion to phenylpyruvic acid, phenylacetic acid, tyrosine, and so forth. The size of the compartments shown in the drawing does not necessarily reflect the true in vivo relationships. The arrows indicate the direction of the main flow of phenylalanine but do not exclude that some back reaction does occur. Some return from $E$ to $A$, for instance, takes place since the reaction of phenylalanine to phenylpyruvic acid is reversible.

easily be estimated:

$$
\frac{V_{\text {plasman }} \times P_{r} \times P_{p}}{t_{t}}
$$

where $V_{\text {plasma }}=$ Evans blue space in milliliters; $P_{r}=$ ratio of total to intravascular plasma proteins $(2.4) ; P_{p}=$ plasma protein concentration in grams per $1.0 \mathrm{ml}$ plasma; and $t_{t}=$ turnover time of plasma proteins in days.

From Equation 3 the lower limit for total plasma protein synthesis of about $17 \mathrm{~g}$ per day per $70 \mathrm{~kg}$ body weight was calculated. Niklas and Poliwoda (15) fed $S^{35}$-methionine to nine normal controls. The lower limit of the daily plasma protein synthesis was found to be of the order of $9.2 \mathrm{~g}$.

On the basis that the average phenylalanine content of plasma proteins is about 6 per cent, 4.9 $\mathrm{mEq}$ phenylalanine was incorporated into plasma proteins. Thus, roughly 4 per cent of all phenylalanine incorporated into total body proteins was found in intra- and extravascular plasma proteins. Expressed in grams of protein, the fraction of plasma protein synthesis from the total body protein formation in Patient J.I. is of the order of magnitude of 3 per cent. However, these values may be considered only a rough approximation of the lower limit, since recycling of phenylalanine prolongs the turnover time of plasma proteins, and the total body protein synthesis in Patient J.I., as calculated from the first straight line, is the upper limit.

Figure 3 illustrates our assumed model; $k$ is the rate constant of the total amount of phenylalanine leaving the free phenyalanine pool, whereof $k_{1}$ is the rate constant of the fraction of phenylalanine leaving compartment $\mathrm{A}$ and entering compartment B. It was assumed that about 90 per cent of the turned-over phenylalanine was used for protein synthesis, therefore, $0.9 \times k=k_{1}$. The rate of free phenylalanine entering the protein precursor pool can be estimated from the incorporation of labeled phenylalanine into plasma

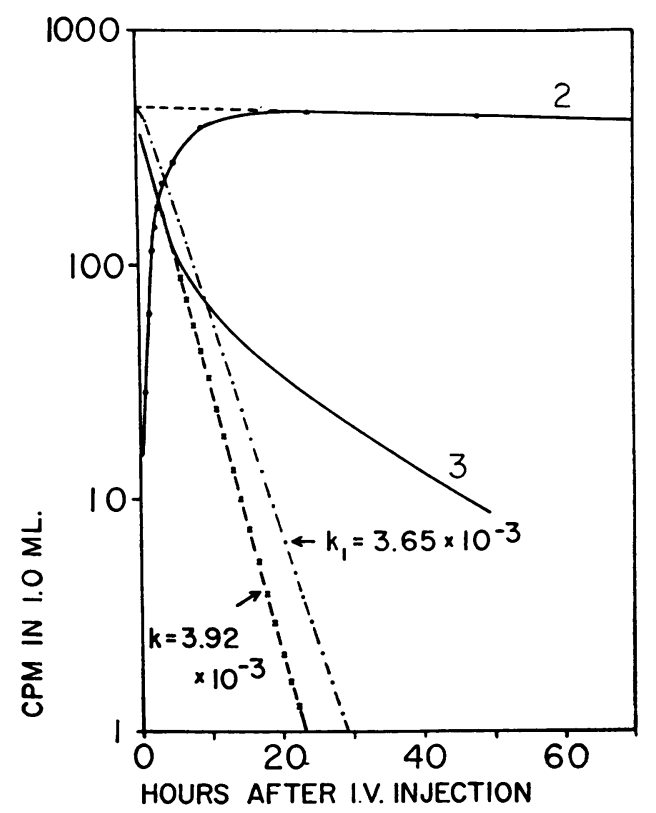

Fig. 4. Disappearance of Labeled Phenylalanine FROM PROTEIN-FREE PLASMA (CURVE 3) AND INCORPORATION of phenylalanine-C ${ }^{14}$ into plasma proteins (curve 2). Extrapolation of the descending part of curve 2 to zero time and subtracting from it the ascending part results in the dashed line -..... The continuation of the experimental first straight line is designated by $-\times-\times-$ For easier comparison with the data in the preceding paper (7), $k$ and $k_{1}$ are presented in the dimension of turnover-time $^{-1}$ in minutes. The time of maximal incorporation (16) is 22.3 hours: $t_{\max }=1 /\left(k_{1}-k_{2}\right) \times \ln \left(k_{1} / k_{2}\right)$. 
proteins. The possibility of making this estimation results from the apparently rapid turnover of $\mathrm{B}$ as compared with A. In this case the kinetics of transfer approaches a simpler model wherein phenylalanine goes directly from $\mathrm{A}$ to $\mathrm{C}$. The actual existence of a compartment $\mathrm{B}$ or several subcompartments $\mathrm{B}^{\prime}, \mathrm{B}^{\prime \prime}$, and so on has been shown in recent years since intermediates of protein biosynthesis have been isolated. However, no evidence from the disappearance curve of free phenylalanine by compartmental analysis was obtained for the presence of compartment B. In J.I..$_{1}$ and N.C. only a very rough graphic approximation could be obtained for $k_{1}$ from the plasma proteins, since the time of maximal incorporation and the maximal value were not accurately known and had to be estimated. In J.I., $k_{1}$ was 45 per cent of $k$ and in N.C. 103 per cent of $k$. However, in Patient ${\mathrm{K} . \mathrm{H}_{.}}_{1}$, in whom the experiment was carried out over a longer time, $k_{1}$ could be graphically determined with better accuracy. Figure 4 shows the semilog plot of the disappearance of free phenylalanine from deproteinized plasma and the incorporation of labeled phenylalanine into plasma proteins; $k_{1}$ was determined to be $3.65 \times 10^{-3}$ in comparison with the value of $3.92 \times 10^{-3}$ found for $k$. The reasonable agreement indicates that turnover in compartment $\mathrm{B}$ is very rapid. This may also serve as additional support for the correctness of our assumption that equilibration of the labeled phenylalanine with the unlabeled free phenylalanine pool is complete, or nearly complete, when the first straight line starts.

\section{SUMMARY}

The rate of total body protein synthesis in three phenylketonuric patients has been calculated from the disappearance of free phenylalanine- $\mathrm{C}^{14}$ from deproteinized plasma. Reasonable agreement with the values of San Pietro and Rittenberg has been found. In one patient the daily formation of plasma proteins was estimated from the disappearance of the labeled isotope from plasma proteins after oral application of $\mathrm{C}^{14}$-labeled phenylalanine. As judged from this experiment, it was felt that protein synthesis in phenylketonuric subjects is of the same order of magnitude as in nonphenylketonuric individuals, and that our values reflect the upper limit of daily protein synthesis in man.

\section{REFERENCES}

1. San Pietro, A., and Rittenberg, D. A study of the rate of protein synthesis in humans. II. Measurement of the metabolic pool and the rate of protein synthesis. J. biol. Chem. 1953, 201, 457.

2. Sprinson, D. B., and Rittenberg, D. The rate of interaction of the amino acids of the diet with the tissue proteins. J. biol. Chem. 1949, 180, 715.

3. $\mathrm{Wu}, \mathrm{H}$., and Bishop, C. W. Pattern of $\mathrm{N}^{15}$-excretion in man following administration of $\mathrm{N}^{15}$-labeled glycine. J. appl. Physiol. 1959, 14, 1.

4. $\mathrm{Wu}, \mathrm{H}$., and Sendroy, J., Jr. Pattern of $\mathrm{N}^{15}$-excretion in man following administration of $\mathrm{N}^{15}$-labeled L-phenylalanine. J. appl. Physiol. 1959, 14, 6.

5. Wu, H., Sendroy, J., Jr., and Bishop, C. W. Interpretation of urinary $\mathrm{N}^{15}$-excretion data following administration of an $\mathrm{N}^{15}$-labeled amino acid. J. appl. Physiol. 1959, 14, 11.

6. Maurer, W. Die Grösse des Umsatzes von Organund Plasmaeiweiss, in Dynamik des Eiweisses. 10. Colloquium der Gesellschaft für Physiologische Chemie, 1959, in Mosbach. Berlin, Springer Verlag, 1960, p. 1.

7. Grümer, H.-D., Koblet, H., and Woodard, C. Phenylalanine metabolism in the phenylpyruvic condition. I. Distribution, pool size, and turnover rate in human phenylketonuria. J. clin. Invest. 1961, 40, 1758.

8. Udenfriend, S., and Bessman, S. P. The hydroxylation of phenylalanine and antipyrine in phenylpyruvic oligophrenia. J. biol. Chem. 1953, 203, 961.

9. Moore, S., Spackman, D. H., and Stein, W. H. Chromatography of amino acids on sulfonated polystyrene resins. Analyt. Chem. 1958, 30, 1185.

10. Grümer, H.-D. Formation of hippuric acid from phenylalanine labelled with carbon-14 in phenylketonuric subjects. Nature (Lond.) 1961, 189, 63.

11. Block, R. J., and Bolling, D. The Amino Acid Composition of Proteins and Foods. Analytical Methods and Results, 2nd ed. Springfield, Ill., Thomas, 1951.

12. Green, H., and Anker, H. S. Kinetics of amino acid incorporation into serum proteins. J. gen. Physiol. 1955, 38, 283.

13. Askonas, B. A., Humphrey, J. H., and Porter, R. R. On the origin of the multiple forms of rabbit $\gamma$-globulin. Biochem. J. 1956, 63, 412.

14. Volwiler, W., Goldsworthy, P. D., MacMartin, M. P., Wood, P. A., Mackay, I. R., and Fremont-Smith, $\mathrm{K}$. Biosynthetic determination with radioactive sulfur of turn-over rates of various plasma proteins in normal and cirrhotic man. J. clin. Invest. 1955, 34, 1126.

15. Niklas, A., and Poliwoda, H. Zur Frage der biologischen Halbwertszeit menschlicher Albumine und Globuline. Biochem. Z. 1954, 326, 97.

16. Zilversmit, D. B. The design and analysis of isotope experiments. Amer. J. Med. 1960, 29, 832. 